\title{
高齢者頭部外傷の現状と課題
}

前田 剛1)2)，片山 容—1)2)，吉野 篤緒1)

1) 日本大学医学部脳神経外科学系神経外科学分野, 2) 青森大学脑と健康科学研究センター

\section{Analysis and Problems of Traumatic Brain Injury in the Aged}

\author{
Takeshi Maeda, M.D., Ph.D. ${ }^{1) 2)}$, Yoichi Katayama, M.D., Ph.D. ${ }^{1) 2}$, and Atsuo Yoshino, M.D., Ph.D. ${ }^{1)}$ \\ 1) Department of Neurological Surgery, Nihon University School of Medicine, 2) Center for Brain and Health Sciences, \\ Aomori University
}

The aged population is rapidly growing across the world. Japan is one of the fastest aging societies, in which people over 65 comprise $25 \%$ of the general population; and this figure is expected to rise to $40 \%$ in 2060. Recently, the aged have come to pose an increasing problem in the management of traumatic brain injury(TBI). Age is closely associated with an increased poor outcome and mortality following TBI. In fact, according to several studies on TBI, age could be the most significant factor in the prediction of outcome. Although the influence of increasing aged TBI is expected to place severe demands on health care resources, especially in developed countries, there are no randomized studies, or treatment guidelines for the aged group. Poor outcome and mortality following TBI are related to the anatomical and physiological vulnerability of the aged brain. Moreover the taking of anticoagulants and antiplatelet agents has been reported to be one cause of a poor outcome following traumatic intracranial hematoma. In this manuscript, we describe the current situation and important issues regarding the management of TBI in the aged.

(Received August 17, 2017 ; accepted September 21, 2017)

Key words : traumatic brain injury, the aged, aging society, Japan Neurotrauma Data Bank Jpn J Neurosurg (Tokyo) $27: 9-16,2018$

\section{はじめに}

わが国の高齢者人口比率(全人口における 65 歳以上の 割合）は，現在 $26 \%$ であり，国民 4 人に 1 人が 65 歳以 上である。 2025 年には $33 \%, 2060$ 年には $40 \%$ に増加す ると推計されている ${ }^{19)}$. 高齢者人口の増加に伴い, 高齢 者頭部外傷も増加している。重症頭部外傷の年齢別発生 頻度は, 20 歳代と 60 歳代の二峰性のピークを認めてい たが，直近の報告では，若年者層のピークが減少し高齢 者のみの一峰性のピークに変化し, さらにピークがより 高年齢層にシフトした $(\text { Fig. 1 })^{9)}$. 高齢者の受傷原因は,
転倒・転落が圧倒的に多く, 加齢に伴う身体能力の低下 が原因として考えられる。交通事故が減少しているとい う受傷原因の変化を考えると, 高エネルギー外傷が減少 し, 高龄者による転倒・転落の増加が，病態の構成にも 大きく影響を及ぼしている，高歯者における重症頭部外 傷は，転帰不良率や死亡率が高( $\left.{ }^{9}\right) 31$. さらに 75 歳以上 では, 75 歳未満の高齢者と比較して転帰不良率や死亡率 が高く，転帰良好率が低(25)。これは，高齢者の脳組織 の解剖学的・生理学的脆弱性に原因があると考元られ, また抗凝固薬や抗血小板薬の内服も転帰不良の原因とし て報告されている。特に近年，死亡率は低下を認めてい 


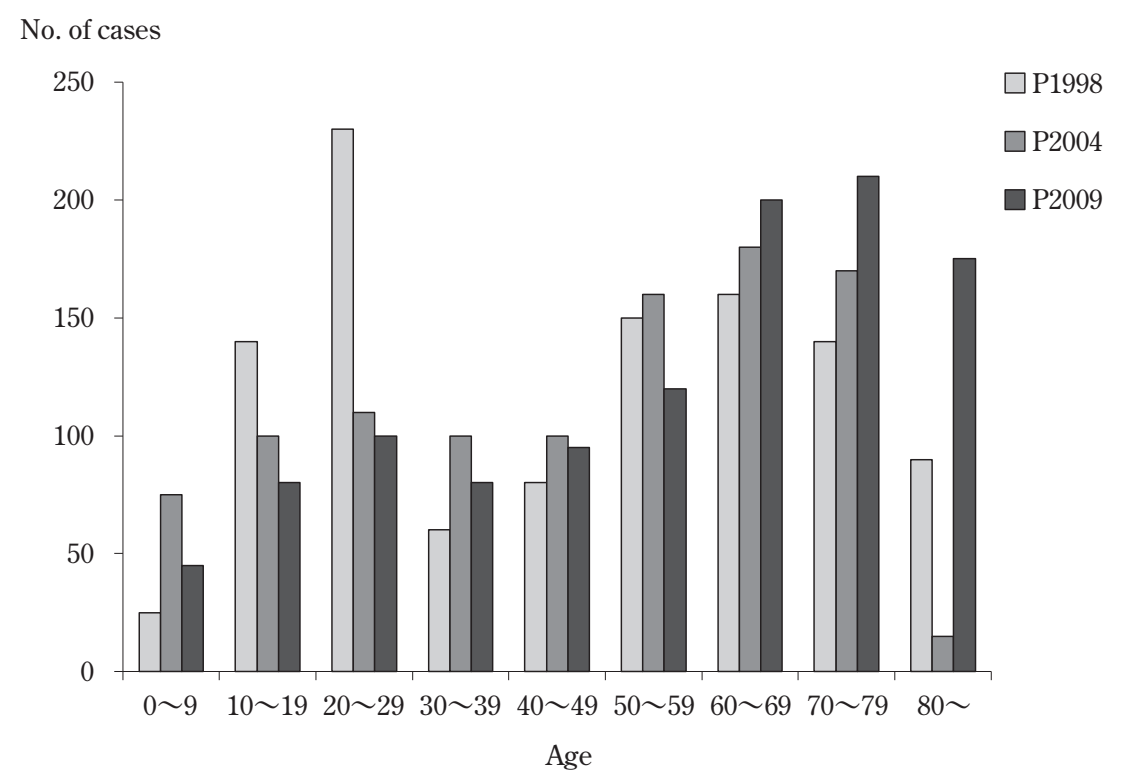

Fig. 1 Age distribution in Japan Neurotrauma Data Bank $(\text { JNTDB })^{9)}$

There were three projects in JNTDB, which were Projects of 98, 04 and 09 . Patients in teens and twenties were suddenly decreased, and seventies and the elderly were significantly increased during only 10 years. (From reference 9 )

るが, 一方で Glasgow Outcome Scale (GOS) 2 (vegetative state) と 3 (severe disability) の生存群における割合が 徐々に増加している ${ }^{31)}$. 重度の後遺症をもつ症例数の増 加は, リハビリテーションや介護に多くの費用を費や す。そのため。急速な高齢化が進むわが国において，高 齢者頭部外傷への予防や対策は早急に解決しなくてはな らない課題である。

本稿では, 高齢者頭部外傷の特徵を解説し, 可及的す みやかに脳神経外科医が行える対策について言及する。

\section{高齢者の解剖学的・生理学的特徵と頭部外傷}

高齢者の頭部外傷は, その解剖学的・生理学的特徵か ら特異的な病態を示す. 高齢者の身体能力的特徵, 解剖 学的特徵, 生理学的特徵が, それぞれ頭部外傷の病態に ぞのような影響を及ぼすか理解しなくてはならない.

高齢者は, 筋力低下などの加齢に伴う身体能力の変化 が認められる。 また, 生理的予備能が低下する一方で, 呼吸器系や循環器系, 代謝系など種々の疾患に罹患して いることが多い. 高齢者の受傷原因は高齢になるに従い 交通事故が減少し, 転落転倒が増加する ${ }^{9)}$. 高齢者の転 倒は平地で起こることが多く, 筋力低下などの身体能力 の低下が，受傷の機転の一因になっている。 その他，判 断力の低下や失神, 起立性低血圧, 内服薬の副作用など
が転倒を引き起こす。糖尿病や呼吸器疾患, 循環器疾患 などの既往症が外傷を契機に進行し, 二次性脳損傷を重 症化させることがあり, その管理には十分注意を要する.

MRI を用いた加齢研究において灰白質は中年からび まん性に減少し始め, 白質は 40 歳まで脳の成熟がみら れるために全体的に増加するが, 以後低下することが報 告されている4). 加齢による生理的な脳萎縮は 50 歳代以 降から始まり, 加齢とともに直線的に進行する ${ }^{17)}$. 脳萎 縮に伴い頭蓋腔の間隙は拡大する。そのため, 高齢者の 頭部に外力が加わると, 頭蓋内で脳が大きく移動し脳挫 傷が発生しやすい. さらに，脳実質や脳血管の脆弱性も 加わり，転倒・転落などの軽微な外傷によっても頭蓋内 出血をきたしやすい。 また，外力に対して大きく脳が移 動するため, 架橋静脈が損傷されやすく硬膜下血腫が起 こりやすい. 日本脳神経外傷学会の頭部外傷データバン ク（Japan Neurotrauma Data Bank：JNTDB）からの報告 では，近年びまん性脳損傷が減少し，急性硬膜下血腫や 脳挫傷などの局所性損傷が増加している，局所性損傷の ひとつである急性硬膜下血腫の年次的年齢的推移は，高 齢者の割合が多くなるに伴い, 高齢者層での増加を認め $ろ^{9)}$. 脳萎縮と頭蓋腔間隙の拡大という加齢脳の解剖学 的特徵が発症機転に大きく関わっている，加えて，頭蓋 腔の間隙が広いことは, 頭蓋内占拠性病変に対する代償 作用が大きく働く．頭蓋内圧方進による症状の出現は遅 
延するが，症状の出現後は急速に悪化してしまう。初診 時に意識状態が比較的良好にもかかわらず，その後悪化 する臨床経過は talk \& deteriorate と呼ばれ, 高齢者に多 (10)12).

高齢者では加齢に伴う生理的変化として, 大脳皮質の 脳血流量や二酸化炭素分圧に対する脳血管の自動調節能 の低下を認める ${ }^{13) 1426) 28)}$ 。重症頭部外傷では, 受傷後直 ちに脳血流量が低下する一方, 急性期にはグルコース代 謝が充進する ${ }^{1) 5)}$. この相対的な虚血状態は二次性脳損 傷の大きな原因であり，この相対的虚血状態の改善が重 症頭部外傷の治療の根幹といっても過言ではない，高齢 者では頭部外傷後の相対的虚血状態が重篤になりやす く, より二次性脳損傷が進行し予後を悪化させる.

\section{慢性硬膜下血腫}

高齢者の代表的脳神経外科疾患のひとつである慢性硬 膜下血腫は，高齢人口の増加や抗血小板・抗凝固療法の 増加, 人工透析患者の増加により今後増加することが予 測されている211)。 わが国における慢性硬膜下血腫の年 齢別発生頻度のピークは, 1970 年代に 50 歳代であった のが，1980 年代に 60 歳代，1990 年代に 70 歳代と年代 ごとに上昇し, 現在では 80 歳代と急速に上昇してい $3^{3(6) 21) 29)}$. 今後, さらに好発年齢がより高齢に移行して いくことが容易に推測される。高齢者における慢性硬膜 下血腫の予後は年齢と相関し, 高齢であればあるほど予 後不良である。また，高齢は慢性硬膜下血腫における再 発因子のひとつであると指摘する報告も散見される ${ }^{15)}$. 直近の報告では, 年齢別発生頻度がピークである 80 歳 代における慢性硬膜下血腫の予後は, 約 40\%が modified Rankin Scale 3〜6 と不良であり, 約 30\%が自宅への退院 が不可であった ${ }^{29)}$. 慢性硬膜下血腫は，予後良好な疾患 と理解されやすいが, 後期高齢者においては, 決して予 後のよい疾患ではなく慎重な治療と観察が必要である。

\section{抗血小板薬・抗凝固薬と頭部外傷}

抗血小板薬・抗凝固薬を内服している高齔者が，頭部 外傷を受傷した場合，外傷性頭蓋内血腫の増大，それに 伴い予後不良の率が高くなる. Inamasu $ら^{8)}$ は, 高齢者の 転倒症例において抗血小板薬・抗凝固薬の内服の有無に 分けて転帰を検討した。その報告によると 85 歳以上で は抗血小板薬・抗凝固薬の内服をしていない群の予後不

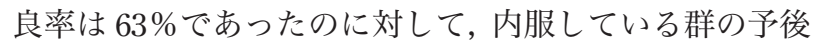
不良率は $82 \%$ であった。各基礎疾患の違いにより塞栓合
併症のリスクは異なり, 頭蓋内出血の有無によっても状 況が異なるため，抗血小板薬・抗凝固薬を内服している 患者が頭部外傷を受傷した場合，休薬して出血傾向を是 正するか否かについての結論は出ていない.リスクと心゙ ネフィットを考慮して各症例で休薬の有無を決定するの が現状である。ワルファリン内服中に重症頭部外傷，ま たは手術が必要な場合，早急に出血傾向を是正する方法 として, 新鮮凍結血漿（10～ $15 \mathrm{ml} / \mathrm{kg} ）$ ，もしくはプロト ロンビン複合体（第 9 因子複合体）500 1,500 IU を投与 する(ただし，プロトロンビン複合体は保険適応外 $)^{20)}$. ビタミンKによるワルファリン作用の拮抗には $4 \sim 24$ 時 間が必要であるので，直ちに拮抗が必要な場合は無効で ある。ただし，新鮮凍結血漿とプロトロンビン複合体の 作用時間は短いため, 同時にビタミン $\mathrm{K}$ の投与を行う。 非ビ夕ミン $\mathrm{K}$ 拮抗経口抗凝固薬/直接作用型経口抗凝固 薬（NOAC/DOAC）に対しては，プロトロンビン複合体 の投与を行う。DOACのダビガトランに対しては，特異 的中和剤イダルシズマブ $5 \mathrm{~g}$ 投与を行う。イダルシズマ ブは投与後， 1 分以内に完全な中和状態となり，その中 和作用は 24 時間持続する ${ }^{23)}$. 脳内出血は prothrombin time-international normalized ratio (PT-INR) $\geqq 2.0$ の場合 に増大しやすいため，1.35 以下にコントロールする。 ま た，血小板は 10 万 $/ \mathrm{mm}^{3}$ 以上，活性化凝固時間 (activated clotting time：ACT）は 159〜180 秒に管理を行う.

\section{高齢者における外科的治療法の効果}

加齢は重症頭部外傷の予後不良因子であるという報告 は，これまで多数報告されてきた (Table 1) ${ }^{716) 18) 27) 30) . ~}$ 56 歳以上では, 死亡率と予後不良率が急激に上昇し, 10 歳年齢が上昇するごとに予後不良率は 40～50\%増加す $3^{7)}$. しかしながら，高齢者の頭部外傷における外科的 治療の効果について検討された報告は少ない。そこで, 高齢者重症頭部外傷における手術療法の効果について, われわれは検討を行った ${ }^{25)}$ 。対象は日本脳神経外傷学会 の JNTDB に登録された 3,194 症例の中で，65 歳以上で あり，受傷 6 力月後の転帰が記録されていた 888 症例で ある。なお，JNTDB の登録対象は，来院時 GCS 8 以下 の症例，経過中に GCS 8 以下に悪化した症例，慢性硬膜 下血腫を除く脳神経外科手術を施行した症例である（た だし，来院時心肺停止症例は除く).

これまでの報告と同様に，65 歳以上の患者は，65 歳未 満の患者に比べ, 受傷後 6 力月における GOS 1 3 3であ る転帰不良群の率や死亡率が有意に高く, GOS 4 と 5 で ある転帰良好群の率が有意に低い（Fig. 2A）。さらに， 
Table 1 Outcome in aged patients with traumatic brain injury

\begin{tabular}{l|c|c|l|c|l}
\hline \multicolumn{1}{c|}{ References } & $\begin{array}{c}\text { Age } \\
\text { (years) }\end{array}$ & $\begin{array}{c}\text { No. of } \\
\text { patients }\end{array}$ & \multicolumn{1}{|c|}{ Unfavorable outcome } & Mortality & \multicolumn{1}{c}{ Poor prognostic factor } \\
\hline Mosenthal 2002 & $\geq 65$ & 153 & $43 \%$ at discharge & $30 \%$ & Increased age, low GCS \\
Susman 2002 & $\geq 65$ & 3,244 & $54 \%$ (dependent living) & $24 \%$ & Increased age \\
Hukkelhoven 2003 & $\geq 65$ & 101 & $85 \%$ at 6 months & $72 \%$ & Increased age \\
Nakamura 2006 & $\geq 50$ & 535 & $80 \%$ at discharge & $61 \%$ & Increased age, mothor vehicle accidents, \\
& & & & & falls, jumps \\
Tokutomi 2008 & $\geq 70$ & 189 & $90 \%$ at 6 months & $69 \%$ & Increased age, early hypoxia \\
Shimoda 2014 & $\geq 65$ & 888 & $87 \%$ at 6 months & $70 \%$ & Increased age, low GCS \\
\hline
\end{tabular}
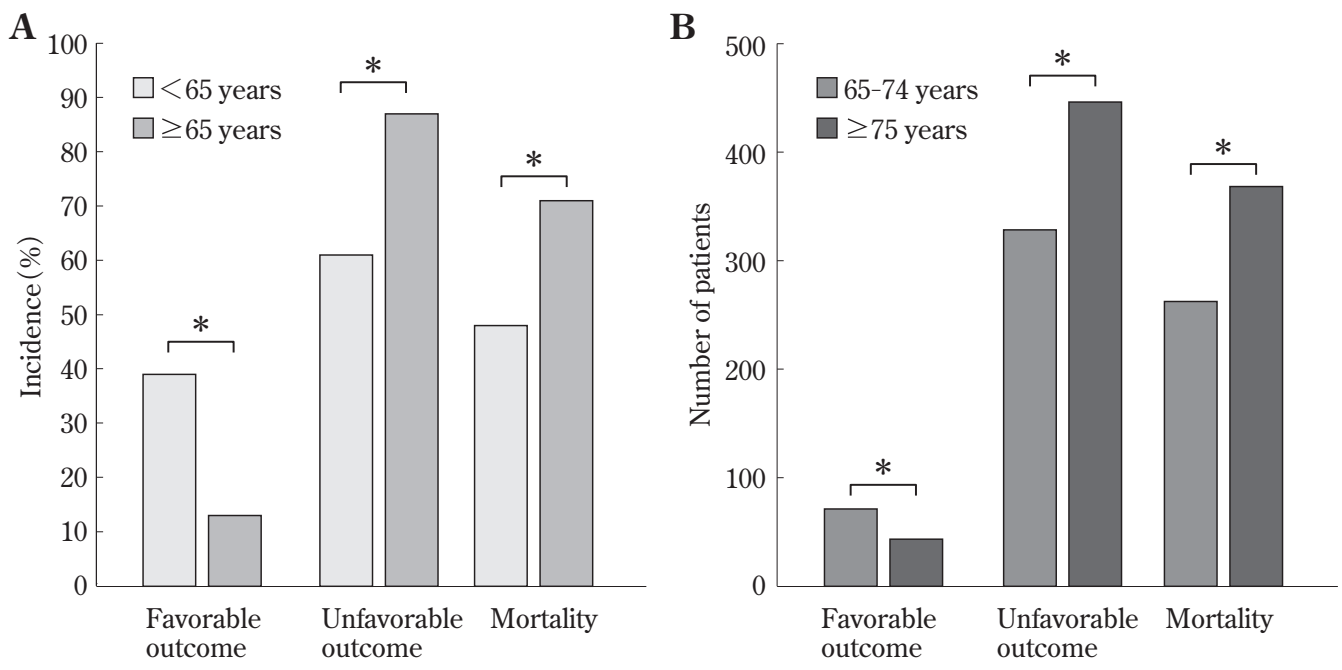

Fig. 2 Comparison of outcome and mortality in different age groups ${ }^{25)}$

A : Younger than 65 years of age versus 65 years of age and older. There were significant differences in outcome and mortality between patients less than 65 years of age and those 65 years of age and older $\left({ }^{*} \mathrm{p}<0.05\right)$.

B : 65-74 years of age versus 75 years of age and older. There were significant differences in outcome and mortality between patients 65-74 years of age and those 75 years of age and older $\left({ }^{*} \mathrm{p}<0.05\right)$. (From reference 25$)$

75 歳以上の高齢者は $65 \sim 74$ 歳の患者に比べ，転帰不良 率や死亡率が有意に高く, 転㷌良好率が有意に低い (Fig. 2B). 外科治療群と保存的治療群の比較では, 外科治療 群において転帰良好例が有意に多く，死亡率が有意に低 い (Fig. 3). 外傷性頭蓋内出血の病変における疾患別の 外科治療の効果では，外科的治療は急性硬膜下血腫にお いて転帰と死亡率を改善し, 脳挫傷において死亡率を改 善した(Fig.4)。しかしながら, GCS 5 以下の患者は GCS 6 以上の患者に比べ, 転帰不良例が有意に多く, 死亡率 が高いことが明らかになった（Fig. 5). 予後予測因子に ついて多変量解析を行ったところ, 75 歳以上が最も転帰 不良に関係する独立因子であり，さらに，来院時の低い GCS が転帰不良に関係していた（ともに p < 0.001) (Table 2). 対照的に外科手術は転帰を改善する可能性があるこ とが明らかになった（p<0.001）（Table 2)，それぞれの
症例において，既往症や個々の身体能力などによる耐術 能の問題はあるものの，GCS 6 以上であれば，年齢は外 科治療の治療制限要因とすべきではない。しかし，GCS 5 以下の高齢者頭部外傷患者に対する外科治療は, 効果 を認めないことが明らかになった。

\section{予 防}

高齢者の転倒による外傷の増加に対して, 足もとの小 さな段差に要注意, 外出は時間に余裕をもって, 悪天候, 夜間の外出は要注意など, 高齢者の転倒予防策をまとめ た「高齢者自らの転倒防止 10 力条」が提唱されている. このような啓蒙活動は非常に大切だが，その効果が出る までには時間を要する. 加齢に対する有効な予防法や薬 剤は, 今のところ報告されていない. 人類にとって加齢 


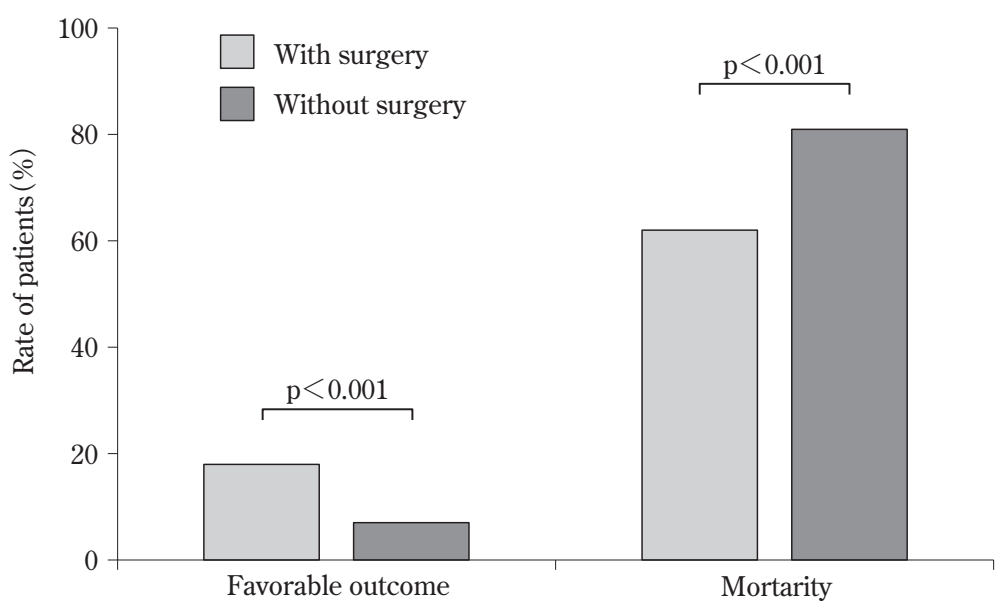

Fig. 3 Effect of surgical management for geriatric patients with traumatic brain injury

Patients who underwent surgery were significantly more likely to have a good outcome and less likely to die than patients without surgery.

ASDH

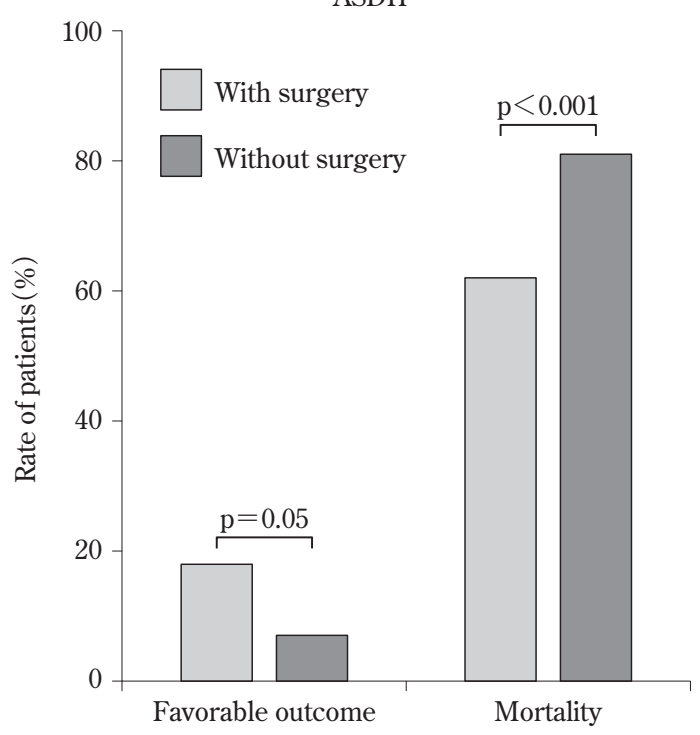

Contusion/ICH

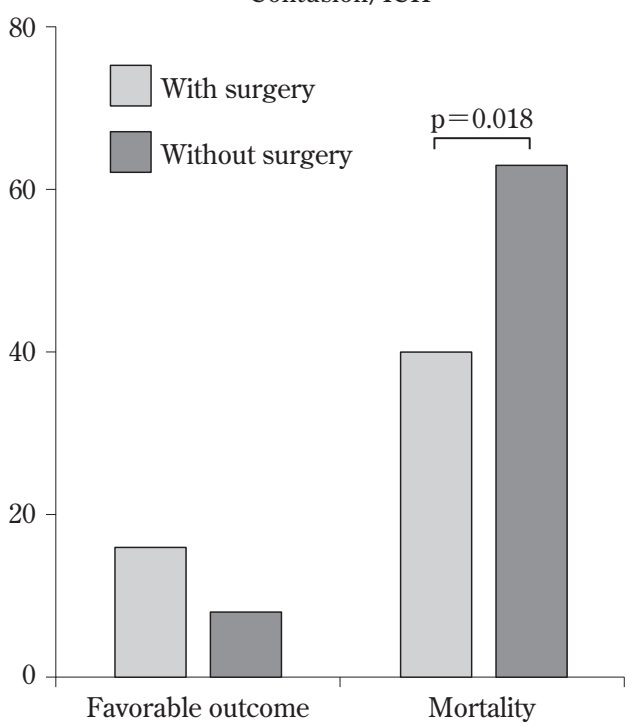

Fig. 4 Effects of surgical treatment for acute subdural hematoma (ASDH) and cerebral contusion/intracerebral hematoma (ICH)

For patients suffering from ASDH, those undergoing surgery were more likely to have a favorable outcome and less likely to have mortality. In patients with cerebral contusion/ICH, those who underwent surgery did not do worse when it came to outcome, and were less likely to die.

は避けて通れない問題であるが，脳神経外科医の日々の 診療において高齢者の転倒を予防することは可能であ る.ベンゾジアゼピンの功罪については，これまで数多 く報告されてきた。高齢者におけるベンゾジアゼピンの 内服と転倒による大腿骨頝部骨折の関係を調べると, 内 服していると骨折がオッズ比で 1.9 倍になると報告され
ている ${ }^{24)}$.もちろん大腿骨䅡部骨折をするような外傷が あれば，転倒による頭部外傷の率も上がると容易に想像 できる。 また, 短時間作用型のベンゾジアゼピンは, 長 時間作用型に比較して転倒発生率が少ないと思われやす いが，実際は両者の転倒発生率に差はない。脳神経外科 医が比較的処方する薬剤の中でも, 転倒を引き起こしや 


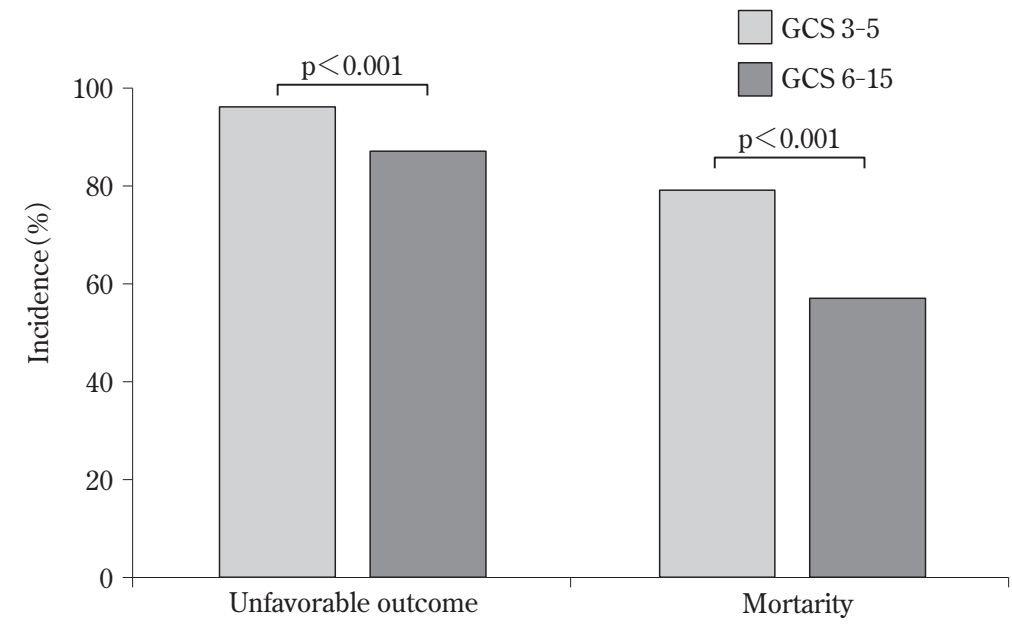

Fig. 5 The effect of the level of coma/disturbed consciousness upon surgical treatment and the outcome

We compared patients with GCS scores of 3-5 on arrival, with those with GCS scores of $6^{-1}$. Patients with GCS scores of $3^{-5}$ had significantly higher rates of unfavorable outcome and mortality than those with GCS scores of 6-15

Table 2 Variables predicting unfavorable outcome for aged patients with traumatic brain injury ${ }^{25}$

\begin{tabular}{l|c|r}
\hline \multicolumn{1}{c|}{ Variable } & Odds ratio $(95 \%$ confidence interval) & p value \\
\hline Age $\geq$ years & $2.72(1.62-4.58)$ & $<0.001$ \\
Early hypotension & $1.94(066-5.67)$ & 0.227 \\
Early hypoxia & $1.84(0.61-5.52)$ & 0.277 \\
Severe GCS score & $2.60(1.52-4.45)$ & $<0.001$ \\
Type of surgery & $0.32(0.17-0.60)$ & \\
$\quad$ Craniectomy and craniotomy & $1.29(0.52-3.20)$ & $<0.001$ \\
Burr-hole evacuation & $0.74(0.43-1.29)$ & 0.580 \\
ASDH & $0.70(0.26-1.9)$ & 0.293 \\
AEDH & $1.01(0.47-2.16)$ & 0.482 \\
Brain contusion/ICH & $1.86(1.00-3.43)$ & 0.983 \\
ICP monitoring & $2.42(0.25-23.60)$ & 0.049 \\
Temperature management & & 0.446 \\
\hline
\end{tabular}

GCS : Glasgow coma scale, ASDH : acute subdural hematoma, AEDH : acute epidural hematoma, ICH : intracerebral hematoma, ICP : intracranial pressure

すい薬が存在する．プレガバリンは, post stroke pain な ぞの中枢性疼痛に有効であるが，70\%以上に何らかの副 作用を認める。そのうち $60 \%$ に転倒を引き起こすような 傾眠やめまいなどの症状を認め, これら副作用の発現率 は, 65 歳以上で, 男性より女性において有意に高い22). また, 慢性疼痛に使用されるトラマドールなどのオピオ イド系鎮痛剤と併用すると，さらに傾眠やめまいなどの 症状が出現しやすくなる。対応策として, 少量からの開 始, 頓服や就寝前の内服でなく, 食後に内服させるなど の服薬指導で大幅に副作用を軽減させることが可能であ
る。このように高齢者の投薬には，細心の注意が必要で ある。

\section{おわりに}

高齢者の頭部外傷は, 先進国を中心に高齢者人口比率 が上昇しているため, 今後世界的な増加が予想される. その治療に関しては，医療経済学的な側面を含め大きな 問題になる可能性がある。年齢は頭部外傷における転㷌 不良に関する独立因子であり, 特に 75 歳以上は最も関 
係が強い.これは, 高齢者の脳組織の解剖学的・生理学 的脆弱性に原因があると考元られ，また抗凝固薬や抗血 小板薬の内服も転帰不良の原因になっている。高齢者の 解剖学的, 生理学的変化は年齢依存性であることに間違 いない，しかし，個人差があることも明白である，今後 個人差を示す指標を基にした研究，治療法の確立，予防 への取り組みが，急速な高齢化社会が進むわが国におけ る脳神経外科医に与えられた重要な課題である。

COI の開示 : 著者は日本脳神経外科学会への COI 自己登録 を完了しています。本論文において開示すべき COI はありま せん.

\section{文 献}

1) Bergsneider M, Hovda DA, Shalmon E, Kelly DF, Vespa PM, Martin NA, Phelps ME, McArthur DL, Caron MJ, Kraus JF, Becker DP : Cerebral hyperglycolysis following severe traumatic brain injury in humans : a positron emission tomography study.J Neurosurg $\mathbf{8 6}:$ :241-251, 1997.

2) Ducruet AF, Grobelny BT, Zacharia BE, Hickman ZL, DeRosa PL, Andersen KN, Sussman E, Carpenter A, Connolly ES Jr : The surgical management of chronic subdural hematoma. Neurosurg Rev $35: 155-169,2012$.

3）藤岡正導，松角康彦，賀来素之，桜間信義，野中信仁， 三浦義一: 慢性硬膜下血腫 100 例の臨床と CT-症状発現 と CT 所見における血腫発育過程一. Neurol Med Chir (Tokyo) 21:1153-1160, 1981.

4) Giorgio A, Santelli L, Tomassini V, Bosnell R, Smith S, De Stefano N, Johansen-Berg H : Age-related changes in grey and white matter structure throughout adulthood. Neuroimage 51: 943-951, 2010.

5) Giza CC, Hovda DA: The new neurometabolic cascade of concussion. Neurosurgery 75 (Suppl 4) : S24-33, 2014.

6) Hirakawa K, Hashizume K, Fuchinoue T, Takahashi H, Nomura K : Statistical analysis of chronic subdural hematoma in 309 adult cases. Neurol Med Chir (Tokyo) $12: 71^{-}$ 83, 1972.

7) Hukkelhoven CW, Steyerberg EW, Rampen AJ, Farace E, Habbema JD, Marshall LF, Murray GD, Maas AI : Patient age and outcome following severe traumatic brain injury: an analysis of 5600 patients. J Neurosurg 99: 666-673, 2003.

8) Inamasu J, Nakatsukasa M, Kuramae T, Nakagawa $Y$, Miyatake S, Tomiyasu K : Influence of age and anti-platelet/anti-coagulant use on the outcome of elderly patients with fall-related traumatic intracranial hemorrhage. Neurol Med Chir (Tokyo) 50:1051-1055, 2010.

9）亀山元信，刈部 博，川瀬 誠，林 俊哲，平野孝幸, 冨永悌二：重症頭部外傷の年齢構成はどのように変化し てきたのか？頭部外傷データバンク【プロジェクト 1998, 2004, 2009】の推移. 神経外傷 $36: 30-36,2013$.

10）川又達朗, 片山容一: Talk and deteriorate 86 症例の検討 臨床像，治療，転帰について。神経外傷 $25: 205-209$, 2003.

11）刏部 博, 亀山元信, 川瀬 誠, 林 俊哲, 平野孝幸, 冨永悌二：血液透析患者に抢ける慢性硬膜下血腫の臨床 像と問題点. 神経外傷 36:196-201，2013.

12）刈部 博，林 俊哲，平野孝幸，亀山元信，中川敦寛，
冨永悌二: 高齿者頭部外傷の特徵と問題点。脳外誌 23: 965-972, 2014

13) Leoni RF, Oliveira IA, Pontes-Neto OM, Santos AC, Leite JP : Cerebral blood flow and vasoreactivity in aging : an arterial spin labeling study. Braz J Med Biol Res 50 : e5670, 2017.

14) Meyer JS, Terayama $Y$, Takashima $S$ : Cerebral circulation in the elderly. Cerebrovasc Brain Metab Rev $5: 122-146$, 1993.

15) Mori K, Maeda M : Surgical treatment of chronic subdural hematoma in 500 consecutive cases : clinical characteristics, surgical outcome, complications, and recurrence rate. $\mathrm{Neu}$ rol Med Chir (Tokyo) $41: 371-381,2001$.

16) Mosenthal AC, Lavery RF, Addis M, Kaul S, Ross S, Marburger R, Deitch EA, Livingston DH : Isolated traumatic brain injury: age is an independent predictor of mortality and early outcome.J Trauma $\quad \mathbf{5 2}:$ 907-911, 2002.

17) Nagata K, Basugi N, Fukushima T, Tango T, Suzuki I, Kaminuma T, Kurashina S: A quantitative study of physiological cerebral atrophy with aging. A statistical analysis of the normal range. Neuroradiology $\quad 29: 327-332,1987$.

18) Nakamura N, Yamaura A, Shigemori M, Ogawa T, Tokutomi T, Ono J, Kawamata T, Sakamoto T : Final report of the Japan Neurotrauma Data Bank Project 1998-2001 : 1,002 cases of traumatic brain injury. Neurol Med Chir (Tokyo) 46: 567-574, 2006.

19）内閣府：平成 28 年版高齢社会白書. http://www8.cao.go.jp/kourei/whitepaper/w-2016/html/ zenbun/s1 1 1.html（2017 年 11 月）

20）日本脳卒中学会, 脳卒中ガイドライン委員会: 抗血栓療 法に伴う脳出血. 脳卒中治療ガイドライン 2015. 東京, 協和企画, 2015, pp.173-176.

21）新阜宏文，松田昌之，半田譲二：老年者の慢性硬膜下血 腫: 統計的観察. 脳外誌 4:359-363, 1995.

22）ファイザー株式会社：8、副作用。リリカ®カプセル (プ レガバリンカプセル）インタビューフォーム(第 8 版), pp.116-133, 2014.

http://image.packageinsert.jp/pdf.php? $\operatorname{mode}=1 \& \mathrm{y}$ jcode $=1190017 \mathrm{M} 1028$ (2017 年 11 月)

23) Pollack CV Jr, Reilly PA, Eikelboom J, Glund S, Verhamme P, Bernstein RA, Dubiel R, Huisman MV, Hylek EM, Kamphuisen PW, Kreuzer J, Levy JH, Sellke FW, Stangier J, Steiner T, Wang B, Kam CW, Weitz JI : Idarucizumab for dabigatran reversal. N Engl J Med 373: 511-520, 2015.

24) Requena G, Huerta C, Gardarsdottir H, Logie J, GonzálezGonzález R, Abbing-Karahagopian V, Miret M, Schneider C, Souverein PC, Webb D, Afonso A, Boudiaf N, Martin E, Oliva B, Alvarez A, De Groot MC, Bate A, Johansson S, Schlienger R, Reynolds R, Klungel OH, de Abajo FJ : Hip/ femur fractures associated with the use of benzodiazepines (anxiolytics, hypnotics and related drugs) : a methodological approach to assess consistencies across databases from the PROTECT-EU project. Pharmacoepidemiol Drug Saf 25 Suppl 1: 66-78, 2016.

25) Shimoda K, Maeda T, Tado M, Yoshino A, Katayama Y, Bullock MR: Outcome and surgical management for geriatric traumatic brain injury: analysis of 888 cases registered in the Japan Neurotrauma Data Bank. World Neurosurg 82 : 1300-1306, 2014

26) Strandgaard S: The cerebral circulation in the elderly : The influence of age, vascular disease, and antihypertensive treatment. Am J Geriatr Cardiol 2 : 32-36, 1993. 
27) Susman M, Dirusso SM, Sullivan T, Risucci D, Nealon P, Cuff S, Haider A, Benzil D: Traumatic brain injury in the elderly: increased mortality and worse functional outcome at discharge despite lower injury severity. J Trauma $\mathbf{5 3}$ : 219-223, 2002.

28) Thomas BP, Liu P, Park DC, van Osch MJ, Lu H : Cerebrovascular reactivity in the brain white matter: magnitude, temporal characteristics, and age effects. J Cereb Blood Flow Metab 34: 242-247, 2013.

29) Toi H, Kinoshita K, Hirai S, Takai H, Hara K, Matsushita N, Matsubara S, Otani M, Muramatsu K, Matsuda S, Fushimi $\mathrm{K}$, Uno M : Present epidemiology of chronic subdural hema- toma in Japan: analysis of 63,358 cases recorded in a national administrative database. J Neurosurg 2017. [Epub ahead of print]

30) Tokutomi T, Miyagi T, Ogawa T, Ono J, Kawamata T, Sakamoto T, Shigemori M, Nakamura N:Age-associated increase in poor outcomes after traumatic brain injury: a report from the Japan Neurotrauma Data Bank. J Neurotrauma 25: 1407-1414, 2008.

31）横田裕行：外傷学における頭部外傷の位置づけ一第 28 回 日本外傷学会総会・学術集会から一. 脳外誌 $23: 942-$ 950, 2014.

\section{高齢者頭部外傷の現状と課題}

\section{前田 剛 片山 容一 吉野 篤緒}

わが国の高齢者人口比率（全人口における 65 歳以上の割合）は，現在 $26 \%$ あ゙り，国民 4 人に 1 人が 65 歳以上である. 2025 年には $33 \%, 2060$ 年には $40 \%$ に増加すると推計されている. 高齢者人 口の増加に伴い, 高齢者頭部外傷も急激に増加している. 高齢者の受傷原因は, 転倒・転落が多く, 加齢に伴う身体能力の低下がその原因と考えられる．高齢者における重症頭部外傷は，転帰不良率や 死亡率が高く, 転帰良好率が有意に低い.これは, 高齢者の脳組織の解剖学的・生理学的脆弱性に原 因があると考えられ，また抗凝固薬や抗血小板薬の内服も転帰不良の原因として報告されている．高 齢者の解剖学的, 生理学的变化は年齢依存性であることに間違いない. 今後個人差を示す指標を基に した研究, 治療法の確立, 予防への取り組みが, 急速な高齢化社会が進むわが国において重要な課題 である. 